Maurer School of Law: Indiana University Digital Repository@ Maurer Law
Indiana Journal of Global Legal

Studies

Volume 21 | Issue 1

Article 4

Winter 2014

\title{
Critical Cultural Translation: A Socio-Legal Framework for Regulatory Orders
}

Laura A. Foster

Indiana University, fosterl@indiana.edu

Follow this and additional works at: http://www.repository.law.indiana.edu/ijgls

Part of the International Law Commons, and the Social and Behavioral Sciences Commons

\section{Recommended Citation}

Foster, Laura A. (2014) "Critical Cultural Translation: A Socio-Legal Framework for Regulatory Orders," Indiana Journal of Global Legal Studies: Vol. 21: Iss. 1, Article 4.

Available at: http://www.repository.law.indiana.edu/ijgls/vol21/iss1/4

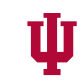

JEROME HALL LAW LIBRARY

INDIANA UNIVERSITY

Maurer School of Law
Bloomingelon 


\title{
Critical Cultural Translation: A Socio-Legal Framework for Regulatory Orders
}

\author{
LAURA A. FOSTER*
}

\begin{abstract}
The making of legal regulatory orders has become increasingly transnational as legal ideas travel and are adopted, discarded, and refigured. Socio-legal scholars have recently turned to the framework of translation to guide examinations of how law changes from one context to the next and how law itself translates and transforms the subjects and objects it governs. Drawing upon science studies and feminist theory, this article develops critical cultural translation as possible socio-legal methodology and praxis for the study of transnational regulatory orders. Furthering this line of inquiry, it addresses the regulation of benefit sharing and the patenting of indigenous San peoples' knowledge in Southern Africa. Critical cultural translation involves a responsibility towards social justice and openness to disorientation, whereby normative legal meanings and language are broken up and reconfigured to allow for a plurality of coalitional politics towards more meaningful social change.
\end{abstract}

\section{INTRODUCTION}

Translation as a framework can enable socio-legal scholars to examine how the law is translated, who does the translating, and who benefits from it. A methodological praxis of translation gives socio-legal scholars tools to ask how practices of translation within the law produce, secure, and reconfigure hierarchies of knowledge production that have material effects on peoples' lives in unequal ways. As a law student and a lawyer, I understood the concept of translation primarily to mean how the law changes from one form to another, moving and being applied to different facts and jurisdictions bound by legal

* Assistant Professor of Gender Studies, Indiana University-Bloomington; Affiliate Faculty, African Studies Program; Affiliate Faculty, Center for Intellectual Property Research, Indiana University Maurer School of Law.

Indiana Journal of Global Legal Studies Vol. 21 \#1 (Winter 2014)

(C) Indiana University Maurer School of Law 
precedent and evidentiary rules. The legitimacy and authority of the law is constructed as dependent upon this narrow notion of translation as dehistoricized and depoliticized. Such construction serves to naturalize and obscure how the law structurally contributes to the making of power and inequality. The movement of law, however, between facts, jurisdictions, and scales is not coherent and stable. Rather, legal and regulatory translations are always historically situated within unequal systems of power.

Translation thus offers a framework to the study of transnational regulatory orders. The making of legal regulatory orders has become increasingly transnational as legal ideas travel and are adopted, discarded, and/or refigured. ${ }^{1}$ Socio-legal scholars have recently turned to the framework of translation to guide examinations of how law changes from one context to the next. ${ }^{2}$ Translation also provides ways of thinking about how law itself translates and transforms the subjects and objects it governs. Legal norms travel as well as the subjects and objects they produce, reinforce, and secure. A socio-legal methodology and praxis of translation, however, remains underdeveloped. Scholars have begun turning to the field of science and technology studies (STS) for additional insights. ${ }^{3}$ STS scholars have deployed translation as a metaphor and a methodology for understanding how scientific knowledge is produced among networks of diverse social actors. ${ }^{4}$ Most

1. See George E. Marcus, Ethnography in/of the World System: The Emergence of Multi-Sited Ethnography, 24 ANN. REV. ANTHROPOLOGY 95, 98 (1995) (arguing for multisited ethnography to study culture within a new world order marked by globalization and transnationalism); Sally Engle Merry, New Legal Realism and the Ethnography of Transnational Law, 31 LAW \& SoC. INQUIRY 975, 993 (2006) (arguing for a new legal realist framework to study law in the current transnational era).

2. See Sally Engle Merry, Human Rights and Gender Violence: Translating INTERNATIONAL LAW INTO LOCAL JUSTICE 2 (2006) (deploying a lens of translation to understand how law moves from one context to another in terms of gender-based violence); ANNELISE RILES, COLlATERAL KNOWLEDGE: LEGAL REASONING IN THE GLOBAL FINANCLAL MARKETS 62 (2011) (deploying notions of translation from science and technology studies to understand how legal technicalities travel across boundaries).

3. RILES, supra note 2, at 58-66; Mariana Valverde, Jurisdiction and Scale: Legal "Technicalities" as Resources for Theory, 18 SocIAL AND LEGAL STUDIES 139 (2009). My use of "methodology and praxis" is not meant to imply a dichotomy between theory and method and/or theory and practice. Rather, critical cultural translation is grounded within a feminist praxis that entails methodological and theoretical interventions.

4. See generally Michel Callon, Some Elements of a Sociology of Translation: Domestication of the Scallops and the Fishermen of St. Brieuc Bay, in POWER, ACTION, AND BELIEF: A NEW SOCIOLOGY OF KNOWLEDGE? 196, 196 (John Law ed., 1986) (describing the scientific and economic controversy of the decling population of scallops in St. Brieuc Bay, and attempts by marine biologists to impose their conservation strategy on others); Adele E. Clarke \& Susan Leigh Star, The Social Worlds Framework: A Theory/Methods Package, in The HaNdBook OF ScIENCE AND TECHNOlogy Studies 113, 113 (Edward J. 
recently, they have begun to consider obstacles to translational research and the movement of science from the bench to bedside or lab to clinic. ${ }^{5}$

This article examines translation as a possible socio-legal methodology and praxis for the study of transnational regulatory orders through examining the regulation of benefit sharing and the patenting of indigenous peoples' knowledge. In particular, this article focuses on indigenous San peoples' struggles over the patenting of Hoodia gordonii (Hoodia) in Southern Africa. ${ }^{6}$ This article's primary goal, however, is to

Hackett et al. eds., 3d ed. 2008) (investigating the social worlds framework through the studies of scientific work practices); Joan H. Fujimura, Crafting Science: Standardized Packages, Boundary Objects, and "Translation", in SCIENCE AS PRACTICE AND CULTURE 168, 168.69 (Andrew Pickering ed., 1992) (utilizing scientific theory and a standardized set of technologies in analyzing the management of collective action across social worlds); BRUNo Latour, REASSEMbling THE SOCIAL: AN INTRODUCTION TO ACTOR-NETWORK THEORY 95-96 (2005) (explaining how cognitive and technical aspects of science are commonplace among sociologists of science); Adele A. Clarke \& Monica J. Casper, From Simple Technology to Complex Arena: Classification of Pap Smears, 1917-90, 10 MED. ANTHROPOLOGY Q. 601, 601 (1996) (describing how classification is of increasing interest in social and cultural studies of science, technology and medicine); Sara Shostak, Translating at Work: Genetically Modified Mouse Models and Molecularization in the Environmental Health Sciences, 32 SCI., TECH., \& HUM. VALUES 315, 315 (2007) (exploring translation through the incorporation of molecular genetics into environmental health research and regulation); Susan Leigh Star \& James R. Griesemer, Institutional Ecology, 'Translations' and Boundary Objects: Amateurs and Professionals in Berkeley's Museum of Vertebrate Zoology, 1907-39, 19 Soc. STUD. OF SCI. 387, 387 (1989) (developing an analytical framework that can be applied to scientific studies); Susan Leigh Star, This is Not a Boundary Object: Reflections on the Origin of a Concept, 35 SCI., TECH., \& HUM. VALUES 601, 601 (2010) (discussing and informing how to study the architecture of boundary objects); Rodrigo Ribeiro, The Language Barrier as an Aid to Communication, 37 SOC. STUD. OF SCI. 561, 561 (2007) (discussing how technology transfer illustrates the multiple levels that ideas operate).

5. See generally Michael Fisher, Lively Biotech and Translational Research, in LIVELY CAPITAL: Biotechnologies, ETHICS, and Governance in Global MaRKeTS 385, 385 (Kaushik Sunder Rajan ed., 2012) (analogizing how forms of biomedical lab life fit into the current transformations of medicine and life sciences).

6. See Rachel Wynberg \& Roger Chennells, Green Diamonds of the South: An Overview of the San-Hoodia Case, INDIGENOUS PEOPLES, CONSENT AND BENEFIT SHARING: LESSONS FROM THE SAN-HOODIA CASE 108-09 (Rachael Wynberg et al. eds., 2009) (providing a detailed account of San-CSIR benefit sharing negotiations). Hoodia gordonii is just one plant among several in the Hoodia genus. Id. The plant is also referred to by the San as !Xhoba. Id. The Indigenous San peoples are some of the earliest inhabitants of Southern Africa. Id. The San characterize themselves as Indigenous peoples comprised of 100,000 individuals, belonging to about 13 different language groups, who live in Botswana, Namibia, Angola, and South Africa with a few living in Zambia and Zimbabwe as well. See Working Group of Indigenous Minorities in Southern Afr., Who are the San?, WIMSA, http://www.wim-sa.org/about-the-san (last visited Dec. 23, 2013). References in this article regarding the San and Hoodia patent law struggles are based upon fieldwork research in South Africa from 2007 to 2009 involving interviews with members of the $\ddagger$ Khomani San and South African San Council who played a key role in negotiating the 
bring together insights on translation from the fields of science studies and feminist theory to develop preliminary sketches for furthering a socio-legal methodology and praxis of critical cultural translation. Yet, what is to be gained by translation? Translation does not simply guide the study of law's movement from one site to the next; it also implies a degree of responsibility. More specifically, this article draws from feminist theory to suggest critical cultural translation as an approach that addresses conditions of power and inequality. We could understand the movement and transformation of translational legal orders without reference to translation, but then hierarchies of knowledge, power, and difference might go unaddressed. Critical cultural translation involves a responsibility toward social justice and an openness to disorientation, whereby normative legal meanings and language are broken up and reconfigured to allow for a plurality of coalitional politics toward more meaningful social change.

\section{Translation and Hoodia Patent LaW STRUGgles}

Translation simultaneously functions as a framework, a metaphor, a methodology, and a praxis for socio-legal inquiry into transnational regulatory orders. I am interested in deploying translation to understand how the law changes from one site to the next. For instance, how are principles of biodiversity conservation translated from the United Nations Convention on Biological Diversity to the South African Biodiversity Act?7 Additionally, I want to attend to how a given regulatory order translates the subjects and objects it governs. I am curious about how the subjects and objects of law also travel as they are produced and secured in new ways. This requires attention to some key interrelated facets of translation. These include the following: (1) historical embeddedness; (2) spatialized entanglements; (3) movement and nonmovement; (4) violence and resistance; (5) uncertainty; and (6) hierarchies of power. This article will explore these dimensions and generate additional insights from science studies and feminist theory through an examination of Hoodia patent law struggles.

Hoodia gordonii is a succulent plant known for generations by indigenous San peoples in Southern Africa that has a variety of uses

San-CSIR benefit sharing agreement. See Rachel Wynberg, Rhetoric, Realism and Benefit Sharing: Use of Traditional Knowledge of Hoodia Species in the Development of Appetite Suppressant, 7 J. OF WORLD INTELL. PROP. 851, 860 (2004). The San communities within South Africa consist of the $¥$ Khomani, !Xun, and Khwe. Id.

7. See Convention on Biological Diversity, June 4, 1993, 1760 U.N.T.S. 397; National Environmental Management: Biodiversity Act of 2004 (Act No. 10, 2004) (S. Afr.). 
such as a source of food, energy, and water. 8 The San have also claimed to use it to ease breastfeeding and treat gassiness in babies. ${ }^{9}$ Hoodia was translated from a scientific discovery into a legal invention in 1998 when researchers with the South African Council for Scientific and Industrial Research (CSIR) obtained a patent on the plant's chemical properties responsible for suppressing appetite. ${ }^{10}$ CSIR then issued patent sub-licenses to Phytopharm, Pfizer, and eventually Unilever to commercialize and develop Hoodia. ${ }^{11}$ Securing a temporary monopoly right over Hoodia's molecular compounds through the regulatory regimes of patent law was of central importance. In the world of the ethno-pharmaceutical industry, the development of plants into pharmaceuticals does not happen without a patent. ${ }^{12}$. CSIR Hoodia patents were essential for moving the plant from the Kalahari Desert to the lab and then on to the commercial world of weight loss products. Their symbolic association as markers of what is new and novel also worked to translate CSIR scientists from mere suppliers of raw material to producers of science and innovation. Patents thus act as legal conduits, enabling translational work from science to law and market, while producing new legal and scientific subjects and objects for global economies. ${ }^{13}$

Patent law, as a regulatory ordering of knowledge, however, is historically embedded. The transformation of Hoodia from nature, to scientific discovery, to patented object is entangled within the colonial histories of bioprospecting and their contemporary residues located within pharmaceutical companies' desires to find the next blockbuster plant-based drug. An understanding of how law translates and reconfigures subjects and objects into and through its governing logics requires attention to the histories of past translations. As Iza Hussin

8. See Wynberg, Rhetoric, Realism, supra note 6, at 854 .

9. See Laura A. Foster, Patents, Biopolitics, and Feminisms: Locating Patent Law Struggles Over Breast Cancer Genes and the Hoodia Plant, 19 INT'L J. CULTURAL PROP. 371,388 (2012) (arguing that patent law functions within gendered and ethno-racialized forms of neoliberal, biopolitics involving the patenting of women's reproductive and intellectual labor within new bioeconomics).

10. See S. Afr. Patent No. $1997 / 03201$ (filed Apr: 15, 1997) (provisional patent); S. Afr. Patent No. 1998/03170 (filed Apr. 15, 1998) (issued Dec. 29, 1999).

11. See Press Release, Phytopharm plc, Phytopharm plc to Develop Natural AntiObesity Treatment (June 23, 1997) (on file with author); Press Release, Phytopharm plc, Phytopharm plc Collaboration with Pfizer to Develop and Commercialize Obesity Drug (P57) (Aug. 24, 1998) (on file with author); Press Release, Phytopharm plc, Phytopharm and Unilever Enter into a License and Joint Development Agreement for Hoodia Gordonii Extract (Dec. 15, 2004) (on file with author).

12. Telephone Interview with Unilever Representative (Mar. 6, 2009).

13. See Foster, supra note 9 , at 390 . 
notes, new understandings of law and its multiple meanings emerge through the historicizing of regulatory translations. ${ }^{14}$

Francis Masson, a colonial botanist with the Royal Kew Gardens in London, published the first known written accounts of Hoodia in 1796.15 Sketching its features and describing its morphology, Masson translated the plant into the standardized language of science. ${ }^{16}$ Converting plants into scientific objects enabled the rise of botany as a field and the production of colonial Empire.17 Transformation of Hoodia into a scientific object also became entangled within new scientific practices of classification and taxonomic ordering. ${ }^{18}$ However, Hoodia was not alone in becoming an object of science. Both plants and humans, as scientific specimens, traveled alongside each other within and through colonial routes of exploration. ${ }^{19}$ Colonial scientists also brought indigenous San and Khoi peoples from the Cape region back to London where they were studied, catalogued, and classified as the lowest order of humans. ${ }^{20}$ Hoodia and the San, therefore, share similar-albeit different-histories of being ranked and ordered in the service of Empire and its production of whiteness. ${ }^{21}$ When products of nature are isolated, purified, and translated through patent law into objects of ownership to be transported, categorized, and commodified, the translational work of

14. See generally Iza Hussin, Misreading and Mobility in Constitutional Texts: A Nineteenth Century Case, 21 IND. J. GLOBAL LEGAL STUD. 145 (2014).

15. See generally Francis MASSON, STAPELIe NOVE: OR, A ColleCtion OF SEVERAL NEW SPECIES OF THAT GENUS; DisCOVEREd IN THE INTERIOR PARTS OF AFRICA (1796).

16. See generally Lorraine Daston \& Peter Galison, The Image of Objectivity, 40 REPRESENTATIONS 81, 81 (1992) (examining how the making of scientific images in the late nineteenth century and early twentieth century contributed to the moralization of objectivity).

17. See Michel Foudault, The ORder of Things: AN ARChaEology of the HuMan SCIENCES 137 (1973) (discussing the shift from ordering knowledge around resemblance to classification); LONDA L. SCHIEBINGER, PLANTS AND EMPIRE: COLONIAL BIOPROSPECTING IN THE ATLANTIC WORLD 7 (2004) ("Historians . . . detail how . . expertise in bioprospecting, plant identification, transport, and acclimatization-worked hand-in-hand with European colonial expansion."); SANDRA G. HARDING, Is SCIENCE MUlTiCULTURAL?: Postcolonialisms, FEminisms, AND EPISTEMOLOGIES 45 (1998) (discussing connection between the development of modern science in Europe and the de-development of indigenous knowledge of peoples in the Americas).

18. See generally FoUCAULT, supra note 17.

19. Cf. Judith A. Carney, Black Rice: The African Origins of Rice Cultivation in THE AMERICAS (2001) (studying the relation between the Atlantic slave trade to the Americas and the trade of slaves and their knowledge of rice cultivation).

20. See Saul Dubow, Scientific Racism in Modern South Africa 24 (1995) (documenting the historical rise of scientific racism within South Africa from the eighteenth century until the late twentieth century).

21. See generally Frantz FANON, BLACK SKIN, White MASKS (1982) (discussing Empire and whiteness). 
patent law becomes haunted by the specter of colonial pasts and the logics that also constructed indigenous peoples as property and objects of ownership. Studies of how the law travels while producing subjects and objects in furtherance of global markets must therefore consider the histories of translation in which the law is embedded.

Methodologies and practices of translation should also consider the spatialized entanglements of legal regulatory orders. Thinking of the law spatially means considering scale and time, while accounting for the "sideways" connections between multiple modes of translation. ${ }^{22}$ This enables an examination of how legal entanglements are simultaneously manifesting, conflicting, and impacting each other. For example, as San peoples began to mobilize against CSIR and its development partners, there was more translation work to do. Deploying the rhetoric of biopiracy and biocolonialism, San political organizers worked to translate Hoodia from a scientific object into a stolen object. ${ }^{23}$ The plant became a symbol of contemporary violence against indigenous peoples linked to a colonial past. ${ }^{24}$ Beset with few resources to legally challenge the patents, the South African San Council and the San turned to the possibilities of benefit sharing. ${ }^{25}$ A San-CSIR benefit-sharing contract was eventually signed whereby 6 percent of CSIR royalties were to be given to a trust for San peoples across Southern Africa. ${ }^{26}$ Thus, translations of Hoodia from a patented object to a stolen object enabled contractual benefit sharing and its regulatory governing structures to come into existence. A lens of translation enables one to focus attention on how Hoodia, as a legal object, changes meaning through the multiple modes of translation at work within struggles over the regulation of scientific knowledge production.

22. See generally Michelle MURPhy, SEIZING THE MEANS OF REPROduction: EnTANGLEMENTS of FEMINISM, HEALTH, AND TECHNOSCIENCE 12 (2012) (studying the sideways connections of 1970 s and 1980 s radical feminist alternative health practices in relation to emerging forms of racialized governance, imperialism, U.S. health policy, and NGOs); JASBIR K. PUAR, TERRORIST ASSEMbLAGES: HoMONATIONALISM IN QUEER TIMES 114-65 (2007) (analyzing a sideways cross-reading of the Lawrence-Garner case in relation to U.S. policy on indefinite detention, affirmative action, gay marriage, and Abu Ghraib torture scandal).

23. See Antony Barnett, In Africa the Hoodia Cactus Keeps Men Alive. Now Its Secret is 'Stolen' to Make Us Thin, THE OBSERVER (June 17, 2001, 6:41 AM), http://www.guardian. co.uk/world/2001/jun/17/internationaleducationnews.businessofresearch.

24. See id.

25. See Wynberg \& Chennells, supra note 6, at 102.

26. Benefit Sharing Agreement, art. 1.5, S. Afr. San Council-CSIR, Mar. 24, 2003 (on file with author). See discussion about this agreement in INDIGENOUS PEOPLES, CONSENT AND BENEFIT SHARING: LeSSONS FROM THE SAN.HoOdia CASE (Rachel Wynberg et al. eds., 2009). 
At the same time, translation can be deployed to understand how regulatory orders travel and move. For example, as a recent signatory to the 2010 Nagoya Protocol on Access to Genetic Resources and the Fair and Equitable Sharing of Benefits (Nagoya Protocol), South Africa is charged with governing and monitoring the access and sharing of genetic biodiverse resources. ${ }^{27}$ South Africa previously began this translation process by participating in negotiations over the Convention on Biological Diversity (CBD), from which the Nagoya Protocol arises. ${ }^{28}$ As a party to the CBD, South Africa moved quickly toward biodiversity conservation and benefit sharing with its 2004 Biodiversity Act and the 2008 Regulations on Bio-prospecting, Access and Benefit Sharing (ABS Regulations). ${ }^{29}$ South Africa's recent ratification of the Nagoya Protocol, therefore, does not significantly change the legal landscape that has already been put into place. South Africa's Minister of Environmental Affairs and Tourism currently requires anyone engaged in the bioprospecting of biodiverse resources for the purposes of research to obtain a permit from the appropriate issuing authority. ${ }^{30}$ Permit applications now require proof of a benefit-sharing agreement with any "indigenous community" that contributed to collection and knowledge of the resources. ${ }^{31}$ Private contracts negotiated between parties are now subject to governmental management and to standards of what is considered "fair and equitable." 32 As the principles of the CBD and its Nagoya Protocol are adapted to the context of South Africa, private benefit-sharing agreements are translated into contractual relations monitored by the state. The movement and making of regulatory orders from one site to another also results in the translation of the relevant legal objects and subjects at stake.

Socio-legal methodologies and practices of translation should also take into account the degrees of movement (and nonmovement) as the subjects and objects of law travel (or not). Legal knowledge production entails the shifting of ideas, texts, and materials, which take on new meanings as they change mediums. As a process of moving something from one form to another, translation generally implies movement, conversion, and transformation to various degrees. For example, South

27. See U.N. Secretariat, Convention on Biological Diversity, Nagoya Protocol on Access to Genetic Resources and the Fair and Equitable Sharing of Benefits Arising from their Utilization to the Convention on Biological Diversity, U.N. Doc. UNEP/CBD/COP/ DEC/X/1 (Oct. 29, 2010) [hereinafter Nagoya Protocol].

28. Id. at 1; Convention on Biological Diversity, supra note 7, at 1.

29. See Biodiversity Act of 2004, supra note 7; Government Notice (GN) R138/2008 (S.

Afr.) [hereinafter ABS Regulations].

30. See Biodiversity Act of 2004, supra note 7, ch. 7 .

31. See ABS Regulations, supra note 29 , ch. 3.

32. Id. ch. 3 , pt. $1, \S 17(3)(a)$. 
African lawmakers transform principles of benefit sharing articulated in the Nagoya Protocol by moving them into the context of South Africa. ${ }^{33}$ Ideas of what may be considered a "fair and equitable" benefit-sharing contract at the international level are being translated from international law into the language of South African law and politics. ${ }^{34}$ Additionally, South African and U.S. patent law transform the Hoodia plant from a plant found in nature to a potentially profitable, patented chemical molecule. ${ }^{35}$ Translation, with its emphasis on movement, is thus both a symptom and a diagnosis of the transnational. ${ }^{36}$ To be sure, translation within legal knowledge production implies movement, but not everything moves. Some legal ideas are intentionally or unintentionally discarded, with positive, negative, or ambivalent effects as they circulate from one medium to the next. As Hoodia is translated from a scientific discovery to a commodifiable invention under patent law, its connections to San histories, practices, and knowledge have failed to travel with it. The San are not recognized under patent law as inventors or owners of Hoodia knowledge. ${ }^{37}$ Thus, as legal meanings and objects travel (or not), traces of their past remain visible and/or fade away. What is translated is equally as important as what is not.

Translation also becomes a process that can enact and reproduce violence. As South Africa translates principles of benefit sharing from the Nagoya Protocol into its national regulations and bureaucracies, it runs the risk of committing violence. In the case of Hoodia, it risks reinforcing the unequal position of indigenous San peoples due to histories of violence, genocide, displacement, and economic impoverishment. ${ }^{38}$ For instance, the regulatory language of biodiversity

33. See Nagoya Protocol, supra note 27.

34. See ABS Regulations, supra note 29 , ch. 3, pt 1, $\$ 17(3)$ (a).

35. See, e.g., U.S. Patent No. 6,376,657 (filed Apr. 15, 1998); S.A. Patent No. 98/3170, supra note 10 .

36. See MERRY, supra note 2, at 135.

37. Indigenous knowledge is often collectively held by a group of individuals, so determination of a sole inventor is difficult. Additionally, Indigenous peoples' knowledge would generally not be considered patentable subject matter because it has not been isolated and made "markedly different" from its natural state. See Laura A. Foster, Situating Feminisms, Patent Law, and the Public Domain, 20 ColuM. J. GeNDER \& L. 262, 311 (2011) (arguing for a notion of situated public domains); Diamond v. Chakrabarty, 447 U.S. 303, 313 (1980).

38. Richard B. Lee, Indigenous Rights and the Politics of Identity in Post-Apartheid Southern Africa, in AT THE RISK OF BEING HEARD: IDENTITY, INDIGENOUS RIGHTS, AND Postcolonial States 80 (Bartholomew Dean \& Jerome M. Levi eds., 2003); ShanE MoRAN, REPRESENTING BUSHMEN: SOUTH AFrICA AND THE ORIGIN OF LANGUAGE (2009); Nigel Penn, "Fated to Perish": The Destruction of the Cape San, in Miscast: NEgotiating THE PRESEnce of THE Bushmen 81 (Pippa Skotnes ed., 1996); Willemien Le RouX \& ALison White, VoICES OF THE SAN: LIVING IN SOUTHERN AFRICA TODAY (2004); Heike 
conservation may supplant or even discard more meaningful ways of doing benefit sharing as informed by indigenous customary laws or the United Nations Declaration on the Rights of Indigenous Peoples. ${ }^{39}$ These alternative legal frameworks may benefit the San and challenge the hierarchical valuing of modern versus traditional scientific knowledge production in more powerful, albeit limited, ways. ${ }^{40}$ Furthermore, in my own translating of indigenous San peoples' struggles to academic audiences, I, too, run the inevitable risk of committing an epistemic violence that obscures the nuances of San peoples' material experiences in South Africa versus Botswana or the relationship between Hoodia and indigenous Khoi peoples. Translation can, therefore, be an act of violence that produces and reinforces power and inequality.

Processes of translation, however, are never in isolation. They are entangled with multiple modes of translation occurring simultaneously. Translation can be about violence as well as resistance and social change. Indigenous peoples resist hegemonic forms of translation as violence through their own modes of counter translation. ${ }^{41}$ For instance, the San transform the language of benefit sharing from an issue of biodiversity conservation to an issue of indigenous peoples' right to selfdetermination through the signing of the San-CSIR agreement. Yet, translation as resistance can also commit violence itself. Compelled to use the language of rights to obtain benefits, the San are forced to place their rights above the rights of other local indigenous peoples, such as the Nama, Damara, and Topnaar, who may also have claims to Hoodia as part of their intellectual heritage. ${ }^{42}$ Thus, is the translation of regulatory orders inevitably always an act of violence? Does the

Becker, The Least Sexist Society? Perspectives on Gender, Change and Violence among southern African San, 29 J. S. AFR. STUD. 5 (2003); Steven Robins, NGOs, 'Bushmen' and Double Vision: The $\neq$ khomani San Land Claim and the Cultural Politics of 'Community' and 'Development' in the Kalahari, 27 J. S. AFR. STUD. 833 (2001).

39. See United Nations Declaration on the Rights of Indigenous Peoples, G.A. Res. 61/295, U.N. Doc. A/RES/61/295 (Sept. 13, 2007); T.W. BENNETT, CUSTOMARY LAW IN SOUTH AFRICA (2004).

40. Science studies scholar, Sandra Harding, has brought attention to the hierarchical binary between modern and traditional knowledge, and how modern western science remains haunted by anxieties of the feminine and the primitive, which have historically been associated with the traditional. See SANDRA G. HARDING, SCIENCES FROM BELOW: FEMINISMS, POSTCOLONIALITIES, AND MODERNITIES (2008).

41. For a discussion on Indigenous peoples' counter-hegemonic social movements see generally LAW AND GLOBALIZATION FROM BELOW: TOWARDS A COSMOPOLITAN LEGALITY (Boaventura de Sousa Santos \& César A. Rodríguez-Garavito eds., 2005); BALAKRISHNAN RAJAGOPAL, INTERNATIONAL LAW FROM BELOW: DEVElopMENT, SOCIAL MOVEMENTS AND THIRD WORLD RESISTANCE (2003).

42. See Wynberg \& Chennells, supra note 6, at 103. 
translation of legal meaning from one form to the next necessarily entail some production and reinforcement of power and inequality?

Translation is messy and can create uncertainty. South Africa's attempts to implement the Nagoya Protocol into South African law will be ongoing as its translations move from one legal medium and context to the next. Implementation of benefit-sharing regulations will change as various government authorities issue permits and review contracts and as the priorities and rhetoric of the nation-state shift. Thus, does translation ever end? Do regulatory orders, with their bureaucratic procedures, remain suspended in continual uncertainty? How might this perpetual uncertainty reinforce and/or threaten the legitimacy of the law or its perceived legitimacy? Processes of translation within the law, therefore, take many forms with differing effects (and affects). As such, they become important as a site of inquiry. Unlocking processes of translation can offer more guidance into the precise ways in which the law produces and reinforces power, inequality, and injustice.

The proceeding section assembles a toolkit for socio-legal studies by bringing together theories of translation from the fields of science studies and feminist studies. References to Hoodia patent law struggles enable a richer discussion of translation and its potential usefulness for socio-legal theory. The central emphasis, however, is not on Hoodia itself, but rather on thinking through and developing a framework of translation to more fully examine how regulatory orders produce, reinforce, and reorient hierarchies of power and inequality.

\section{ASSEMBLING A FRAMEWORK OF TRANSLATION}

Assembling a framework is an act of translation itself. It necessitates an understanding of how translation is taken up in different disciplines. The fields of science studies and feminist studies, in particular, have developed theoretical frameworks of translation that may be useful for socio-legal scholars. The field of science studies deploys translation to trace networks and social worlds of people, ideas, and things in order to understand how experts translate science in relation to nonscientists. ${ }^{43}$ For instance, Michel Callon and Bruno Latour examine the translational practices of scientific experts, while demonstrating how experts impose their own ways of knowing onto others. ${ }^{44}$

43. See generally Callon, supra note 4; Clarke \& Star, supra note 4; Fujimura, supra note 4; LATOUR, supra note 4; Clarke \& Casper, supra note 4; Shostak, supra note 4; Star \& Griesemer, supra note 4; Star, supra note 4; Ribeiro, supra note 4.

44. Callon, supra note 4; LATOUR, supra note 4. 
Competing notions of translation, however, emerge within science studies. For example, the work of Susan Leigh Star and James Griesemer on boundary objects studies multiple modes of translation across diverse social worlds as scientists work in collaboration, rather than through imposition, with nonscientists. ${ }^{45}$ Socio-legal scholars can thus benefit from parceling out the different ways in which translation is conceptualized within science studies. Feminist theory also provides insights into translation. ${ }^{46}$ Feminist scholars such as Gayatri Spivak and Judith Butler, in particular, articulate "cultural translation" as an ethical responsibility to generate coalitions for social change based upon shifting and multiple ways of knowing, being, and becoming, rather than on fixed locations. ${ }^{47}$ Practices of translation, premised on a methodology and praxis of cultural translation, aim to produce new subjects and orderings of knowledge based upon multiple, embodied, and situated ways of knowing that allow for contradiction and change ${ }^{48}$ This section articulates these various disciplinary renderings of translation as starting points for engendering socio-legal understandings of translation within the law.

For the sake of clarity, this section distinguishes three ways of articulating translation. Stabilizing translations are what the law and legal experts do to produce new subjects, objects, networks, and orderings of knowledge. Stabilizing refers to acts of translation that

45. Star \& Griesemer, supra note 4; Star supra note 4.

46. Gayatri Chakravorty Spivak, The Politics of Translation, in THE TRANSLATION STUDIES READER 397 (Lawrence Venuti ed. 2004) (1992); JUDITH BUTLER, PRECARIOUS LIFE: THE POWERS OF MOURNING AND VIOLENCE (2006); Lori Chamberlain, Gender and the Metaphories of Translation, 13 Signs: J. WOMEN CULTURE \& SOC'Y 454 (1988); Claudia de Lima Costa, Being Here and Writing There: Gender and the Politics of Translation in a Brazilian Landscape, 25 SIGNS: J. WOMEN CULTURE \& SOC'Y 727 (2000); Donna Haraway, Situated Knowledges: The Science Question in Feminism and the Privilege of Partial Perspective, 14 FEMINIST STUD. 575 (1988); Hala Kamal, Translating Women and Gender: The Experience of Translating "The Encyclopedia of Women and Islamic Cultures" into Arabic, 36 WoMEN's STUD. Q. 254 (2008); N. Rajaram \& Vaishali Zararia, Translating Women's Human Rights in a Globalizing World: The Spiral Process in Reducing Gender Injustice in Baroda, India, 9 GLOBAL NETwORKS 462 (2009); Kornelia Slavova \& Ann Phoenix, Living in Translation: Voicing and Inscribing Women's Lives and Practices, 18 EUR. J. WOMEN's STUD. 331 (2011); Lucy Tatman, Subjects Through Translation, 18 EUR. J. WoMEN's STUD. 425 (2011); Millie Thayer, Translations and Refusals: Resignifying Meanings as Feminist. Political Practice, 36 FEMINIST STUD. 200 (2010); Linda M.G. Zerilli, Toward a Feminist Theory of Judgment, 34 SIGNS: J. WOMEN CULTURE \& Soc'Y 295 (2009).

47. Spivak, supra note 46 , at 322 ; BUTLER, supra note 46 , at 47.

48. See Haraway, supra note 46 , for a discussion on feminist methodology and objectivity of situated knowledge. 
reinforce and secure hierarchies of knowledge production. 49 Critical translations form a basis for methodologies and practices of translation. They are what socio-legal scholars can do to unpack the circuitry of regulatory orders and the ways they reinforce and produce asymmetries. Critical translations are what guide an examination of stabilizing translations. Cultural translations are what socio-legal scholars can do to produce meaningful coalitions toward better and more socially just ways of doing law (and science). Cultural translation is meant to ensure that our critical methodologies of translation actually work toward social justice. In other words, critical translations investigate stabilizing translations to move toward cultural translation. Flexibly demarcating translation in this manner enables an analysis of how such practices simultaneously relate. Delimiting translation in this manner, however, is not meant to be prescriptive or universal; rather, it is meant to serve as an initial guidepost. The point of the discussion herein is to raise more questions, rather than to provide clear answers.

I contend that socio-legal scholars would be well served by drawing upon the insights of both science studies and feminist studies in generating more meaningful dialogues regarding regulatory translations. ${ }^{50} \mathrm{~A}$ contingent suturing and unwinding of these fields provides a more robust theoretical foundation for socio-legal scholars to understand processes of translation within regulatory orders. I thus argue for a notion of critical cultural translation that enables understandings of how law and science deploy stabilizing translations to secure, construct, reinforce, and produce lines of inequality in new ways.

Assembling these scholarly fields together also becomes an act of translation itself as I draw upon my own intimacy, knowledge, expertise, and training in these fields. Translation can be a marker of expertise and the ability to navigate between social worlds. ${ }^{51}$ Yet,

49. Latour uses the term stabilization to refer to how scientists stabilize facts through processes of translation. See generally BRUNO LATOUR, ScIENCE IN ACTION: HOW TO FOLLOW SCIENTISTS AND ENGINEERS THROUGH SOCIETY (1987). I am using the term in a more political sense of not just stabilizing facts, but stabilizing normative assumptions that reinforce hiearchies of social inequality.

50. This is not to imply a fixed border between these fields. Many of the science studies scholars engaged in work on translations are valuable contributors to feminist science studies critiques of knowledge, power, and inequality. This is critical for socio-legal scholars to remember and give citational authority to. Scholars within these fields thus share overlapping interests, even as their emphasis may differ. Much work on translation in science studies has been further expanded upon by feminist science studies scholars. See Star \& Griesemer, supra note 4; Fujimura, supra note 4; Clarke \& Casper, supra note 4; Shostak supra note 4; Clarke \& Star, supra note 4.

51. Sheila Jasanoff, Breaking the Waves in Science Studies: Comment on H.M. Collins and Robert Evans, 'The Third Wave of Science Studies', 33 Soc. STUD. ScI. 389, 390 (2003). 
translation across disciplinary bounds is always fraught with tension and territorial claims to legitimacy. 52 This is particularly so for feminist scholars and others who are located unequally within the privileged rationalities and materialities of the academy and its related institutions. Translation thus begins by recognizing our own various privileged and inequitable positions. Thus, I proceed cautiously, guided by a feminist science and the politics of "interpretation, translation, stuttering, and the partly understood."53

\section{A. Actor-Network Theory and Critical Translation of Imposition}

Scholarship within science studies examines the making of scientific knowledge through the framework of translation. Translation is theorized through two related, yet distinct, approaches within science studies, which include actor-network theory (ANT) and the study of boundary objects. ${ }^{54}$ In terms of ANT, translation is both what scientists do and a critical research framework for studying how science and technology structure power relationships through imposition. ${ }^{55}$ Although critical in its approach, feminist science studies scholars have criticized ANT for failing to understand hierarchies of knowledge production in terms of gender and racial inequality. ${ }^{56}$ Despite its limitations, its focus on translations of expertise between scientists and nonscientists offers important insights for socio-legal studies. This section will focus on the central work of importance by Michel Callon under ANT and ask how it might contribute to a socio-legal methodology and praxis of translations. ${ }^{57}$

In his study of the domestication of scallops, Michel Callon shows how researchers impose their own scientific frameworks upon others

52. Feminist scholars have also brought attention to how interdisciplinary scholarship requires difficult practices of translation across disciplinary bounds. See generally Marjorie Pryse, Trans/Feminist Methodology: Bridges to Interdisciplinary Thinking, 12 NWSA J. 105 (2000); Judith A. Allen \& Sally L. Kitch, Disciplined by Disciplines: The Need for an Interdisciplinary Research Mission in Women's Studies, 24 FEMINIST STUD. 275 (1998); Cindi Katz, Disciplining Interdisciplinarity, 27 FEMINIST STUD. 519 (2001).

53. Haraway, supra note 46 , at 589 .

54. Shostak, surpa note 4 , at 2 .

55. Callon, supra note 4 , at 197.

56. Nelly Oudshoorn \& Trevor Pinch, User-Technology Relationships: Some Recent Developments, in THE HANDBOOK OF SCIENCE AND TECHNOLOGY STUDIES 547 (Edward J. Hackett, et al. eds., 2008).

57. Callon, supra note 4. Bruno Latour also makes similar suggestions and writes in collaboration with Callon. See generally, LATOUR, supra note 49; Michel Callon \& Bruno Latour, Unscrewing the Big Leviathan, in ADVANCES IN SOCIAL THEORY AND METHODOLOGY: TOWARD AN INTEGRATION OF MICRO- AND MACRO-SOCIOLOGIES (K. KnorrCetina \& Aaron Victor Cicourel eds., 1981). 
through translation. His analysis of translation reads as a step-by-step guide to studying translation. Graphs and flow-charts are used to detail the complicated loops of translation processes. Callon identifies four key moments within translation: (1) problematization; (2) interessement; (3) enrolment; and (4) mobilization. ${ }^{58}$ Problematization is when scientists assert their own definition of the problem and identify collective actors with designated goals and interests (e.g., fishermen, scallops, scientific colleagues) to align around the newly framed issue. ${ }^{59}$ Relevant social actors are identified at this stage but not yet enlisted.

The process of problematization raises important questions that can help guide a study of legal regulatory translations. How do certain experts define a legal problem from the beginning? Whose needs and interests shape the legal experts' formulation of the problem? What types of social actors are identified to form a potential alliance around the problem? In terms of Hoodia patent law struggles, socio-legal scholars might ask how certain experts define the problem of biodiversity conservation when translating the goals of the Nagoya Protocol to the South African context. Who benefits from the formulation of access and benefit sharing as a technique for conserving biodiverse resources, rather than a strategy for indigenous peoples' selfdetermination? How do experts identify social actors (i.e., plants, researchers, indigenous peoples) for possible alliance in support of contractual benefit sharing?

Callon specifies interessement as the second stage within the process of translation. ${ }^{60}$ This denotes the locking of collective actors into place to facilitate alliance and generate their actual enrollment as allies. ${ }^{61}$ The difficulty is that social actors are often defined in ways that hinder alliances. ${ }^{62}$ Scientists must therefore build devices that interest social actors in aligning. This involves redefining the properties and identities of social actors, which may sever their relationship with other entities. ${ }^{63}$ Interessement is about generating interest where alignment has not yet occurred. ${ }^{64}$ Emphasis on interessement and its devices provides further nuance into emerging socio-legal studies of translation. What are the translational devices of interessement, of translation? How do experts interest social actors in affiliating with a stated problem? For example, in her article for this special journal issue,

\footnotetext{
58. Callon, supra note 4, at 203-19.

59. Id. at 203-06.

60. Id. at 206-14.

61. Id.

62. Id. at 208.

63. Id.

64. Id. at 207.
} 
Andrea Ballestero demonstrates how numbers and calculations are used to interest actors in the human rights of water, translating such rhetoric into a new political context. ${ }^{65}$

Interessement also generates interest and alignment among both human and nonhuman actors. ${ }^{66}$ In the case of Hoodia, what technological devices are used to align the plant to scientific interests? How are Waring blenders; rotary evaporators, column chromatography, and bioassays used to align Hoodia into the interest of suppressing appetite? ${ }^{67}$ How do they work to dissociate Hoodia from its connections to the land and San histories and heritages? Socio-legal scholars might also ask what devices were used to interest members of the San community in contractual benefit sharing. What reports, images, documents, presentations, statistics, numbers, and technology were used? Emphasis on the devices and technicalities of translation, therefore, becomes important for understanding how human and nonhuman actors are encouraged to align with certain legal problematizations.

Socio-legal scholars, however, are poised to depart from Callon by bringing more attention to not only the moments of association, but also dissociation. How and what devices are used to generate interest and alignment in ways that encourage social actors to abandon and become disconnected from previous affiliations? How might such dissociations prove harmful? For example, what devices are used to interest San peoples in the property logics of contractual benefit sharing and move them away from their own less propertied belief systems? An emphasis on devices enables insights into what socio-legal scholar Mariana Valverde calls the "technicalities" of law. 68

Generating interest may or may not lead to Callon's third stage of translation, which he names as "enrolment."69 This involves the multilateral negotiations used to ensure interested entities become enrolled allies. ${ }^{70}$ Not all actors, however, will become enrolled. ${ }^{71}$ Callon suggests several important questions at this stage. What are the complex negotiations within processes of translation? What techniques are involved? Are strategies, for example, of physical violence,

65. See generally Andrea Ballestero, What is in a percentage? Calculation as the Poetic Translation of Human Rights, 21 IND. J. GLOBAL LEGAL STUD. 27 (2014).

66. Callon, supra note 4 , at 209.

67. See S. Afr. Patent No. $98 / 3170$, supra note 10 , for discussion of technologies used in the making of Hoodia properties into appetite suppressant invention.

68. See Valverde, supra note 3.

69. Callon, supra note 4, at 211-14.

70. Id. at 211 .

71. Id. 
seduction, or implied consent used?72 Such questions may also be applied to the context of Hoodia patent law struggles. How do scientists change experiments and alter clinical trials to get the plant to suppress human appetite? How do members of the South African San Council negotiate with members of their community to agree to benefit sharing? These become important questions for understanding how law is translated between contexts through complex negotiations.

Legal meanings and rhetoric must be accepted, in whole or in part, by receiving parties for law to take hold. ${ }^{73} \mathrm{~A}$ key to understanding translation, however, may be found within modes of rejection as well as acceptance. Socio-legal scholars might strengthen studies of translation by also focusing on processes of nonenrollment. For instance, Hoodia patent law struggles involve negotiations that did not result in successful enrollment. Scientists were never able to get patented Hoodia molecules to suppress appetite in humans without side effects. ${ }^{74}$ Not all members of the San community agreed that contractual benefit sharing was the right thing to do. ${ }^{75}$ Thus, when and why do negotiations toward enrollment fail? How might such failures indicate resistance to and the reconfiguring of translation? How might a lack of enrollment signal agency for the human and nonhuman actors refusing to accept a role within the network?

Finally, translation involves the mobilization of these networks through representative spokesmen. ${ }^{76}$ Among the social actors enrolled in the network, only a few are selected to represent the whole.77 Concerns arise over who gets to speak for whom. ${ }^{78}$ Such questions of representation also become important for socio-legal understandings of regulatory orders. For instance, how might a few select plants (i.e. Hoodia gordonii) stand in for all the plants in the Hoodia genus? How does one member of the South African San Council become the dedicated spokesperson for the entire South African San Council and San community? To discern hierarchies of power and inequality within

72. Id. at 214 .

73. See MERRY, supra note 2, at 135.

74. See Wendy AM Blom et al., Effects of 15-d Repeated Consumption of Hoodia Gordonii Purified Extract on Safety, Ad Libitum Energy Intake, and Body Weight in Healthy Overweight Women: A Randomized Controlled Trial, 94 AM. J. CLINICAL NUTRICIAN 1171, 1180 (2011).

75. See generally Saskia Vermeylen, From Life Force to Slimming Aid: Exploring Views on the Commodification of Traditional Medicinal Knowledge, 28 APPLIED GEOGRAPHY 224 (2008) (exploring the range of opinions of commodification in the San communities of South Africa).

76. Callon supra note 4, at 214-219.

77. Id. at 214 .

78. $I d$. 
processes of translation, it is also important to ask who is not permitted to speak. What other relevant types of Hoodia plants are ignored? Who are the San that are excluded and why?

According to Callon, translation is a series of displacements and transformations as actors either change their interests to meet the framework of the researchers or refuse to follow this framework. ${ }^{79}$ Regardless of its outcomes, translation brings networks of actors into a relationship with one another, even if only temporarily. As Callon notes, translation is a process and it becomes a mechanism in which "certain entities control others." 80 Translation, therefore, leads to networks in which inscriptions, devices, and actors (human and nonhuman) are brought together into interaction with one another. Central to ANT and the work of Callon (and Latour) is the assumption that translation is about control and imposition. ${ }^{81}$ Translation is about issues of expertise and how experts impose their way of thinking about a problem onto others.

Critical translation, through ANT, studies force, appropriation, and imposition. It concerns processes by which actors create lasting asymmetries by translating the will of others into a language of their own and imposing their own sense of space and time. ${ }^{82}$ Emphasis is also placed upon nonhuman actors as autonomous. ${ }^{83}$ Callon's work, for example, focused on the sea scallop as the actor to be interested, enrolled, and represented. ${ }^{84} \mathrm{~A}$ methodology of critical translation, highlighting force and nonhuman actors, provides insights for sociolegal scholars interested in the technicalities of regulatory translations. ANT, however, has its weaknesses. Vivian Lagesen notes that feminists critique ANT for its failure to address power asymmetries related to gender and its singular focus on small groups of scientists, which ignores the invisible labor of women within technoscience. ${ }^{85}$ Nevertheless, Lagesen begins to look toward ANT for thinking about gender as a translational process of reassembling human and nonhuman elements. ${ }^{86}$

Translation, as developed under ANT, also enhances considerations of translation already emerging within socio-legal studies. For example, Sally Merry's work outlines how the language of human rights is

79. Id, at 223 .

80. Id. at 224 .

81. Fujimura, supra note 4 , at 170.

82. Ribeiro, supra note 4 , at 578 .

83. See Callon \& Latour, supra note 57 , at 286.

84. See Callon, supra note 4.

85. Vivian Anette Lagesen, Reassembling Gender: Actor-Network Theory (ANT) and the Making of the Technology in Gender, 42 SOC. STUD. SCI. 442, 443 (2012).

86. Id. 
appropriated and translated into local social movements and legal consciousness. ${ }^{87}$ Merry defines translation as the process by which human rights ideas are appropriated from elsewhere and adjusted to fit local contexts. 88 Specifically, she deploys translation to study how gender-based violence programs are translated to other countries. ${ }^{89}$ Merry notes that legal ideas do not have to be translated, but they are more likely to take hold if they are. ${ }^{90}$ According to Merry, translation entails three dimensions.91 First, legal ideas are communicated and framed through local cultural narratives and conceptions. ${ }^{92}$ Second, they are adapted to local structural conditions. ${ }^{93}$ Third, they may be expanded to address a different group of legal subjects. ${ }^{94}$ Translation, therefore, according to Merry, involves framing, adapting, and expanding. Human rights ideas are translated, but never fully indigenized, as they continue to retain their emphasis on choice, autonomy, and the individual. ${ }^{95}$ ANT's notions of translation may provide a more nuanced approach to Merry's examination of the translation of legal ideas and the ways they are framed and adapted to local contexts. For example, one might ask what specific devices are used to interest and enroll allies in a human rights framing of genderbased violence? Or how do certain allies become representative spokespersons for a human rights understanding of gender-based violence? ANT's emphasis on force and imposition, however, limits a discussion of how translation involves complex negotiations that do not always involve force. Nevertheless, it provides additional points to consider in developing a socio-legal methodology and praxis of critical cultural translations.

\section{B. Boundary Objects and Critical Translation of Collaboration}

Science studies also offer insights for a socio-legal study of translation when social actors are collaborating. As an alternative to critical translations where researchers are imposing their will, Star and Griesemer provide ways of studying translation in the context of collaboration. ${ }^{96}$ In their study of amateurs and professionals at

\footnotetext{
87. MERRY, supra note 2, at 134.

88. Id. at 135.

89. Id. at 134 .

90. Id. at 135 .

91. Id. at 136 .

92. $I d$.

93. Id.

94. Id. at 137.

95. Id.

96. See generally Star \& Griesemer, supra note 4.
} 
Berkeley's Museum of Zoology, Star and Griesemer find that translation across different social worlds requires standardized sets of methods and boundary objects. ${ }^{97}$ As groups from different social worlds collaborate together (e.g., researchers, collectors, trappers) to increase the museum's collection of specimens, they create various boundary objects. ${ }^{98}$ Such objects simultaneously have a common structure across social worlds, while also taking on different meanings within those worlds.99 Boundary objects can include diagrams, atlases, maps, checklists, and standardized forms to enable translation. ${ }^{100}$ They will mean different things to different groups, but they have some common elements. ${ }^{101}$ Star and Griesemer deploy boundary objects to understand collaboration, but they note how such objects secure scientific authority among diverse social worlds. ${ }^{102}$ Professional researchers with the museum, for example, enrolled allies (e.g., amateur trappers and collectors) through checklists for collecting specimens. ${ }^{103}$ Researchers gained authority over time as collectors and trappers became willing to adhere to the museum's information-gathering standards through the checklists. ${ }^{104}$ Boundary objects, therefore, enable different social worlds to temporarily come together to exchange information for furthering a shared interest, while maintaining asymmetries of scientific knowledge production in the midst of collaboration.

In contrast to Callon, Star and Griesemer use boundary objects to understand translation through an ecological approach by considering the viewpoints of all social worlds, rather than how researchers impose their will upon others. ${ }^{105}$ Attention is directed to the multiple translations going on at the same time between social worlds without privileging one or the other. ${ }^{106}$ Thus, translations are not assumed to be coherent. Similar to ANT, Star and Griesemer consider the "flow of objects and concepts through the network of participating allies and social worlds," but their focus is more on the enterprise as a whole. ${ }^{107}$ Boundary objects, with their sense of collaborative meaning making, also differ from Callon's notion of devices, which are used to compel meaning. Theorizing translation through boundary objects, however,

97. Id. at 392.

98. Id. at 393 .

99. Id.

100. Id. at $410-11$.

101. Id. at 393.

102. Id. at 408-12.

103. Id. at 406.

104. Id.

105. Id. at 389 .

106. Id.

107. Id. 
pays less attention to the nonhuman actors prevalent in ANT, so its ecological approach remains bounded. ANT, therefore, provides a more useful guide in addressing the role of nonhuman matter within translation. Star and Griesemer's work also does not address long-term coalitions, but rather temporary alliances with social worlds that remain far apart. Their work is thus limited in understanding histories of translation over time. Joan Fujimura recognizes such limitations and offers the notion of "standardized packages" as an important alternative to understanding translation. 108

Despite its limitations, translation through notions of boundary objects, for example, can open up an examination of the social worlds of Hoodia. Its ecological approach broadens the inquiry to include multiple translations of not just the scientist/inventors, but also the San, environmental activists, Hoodia farmers, government officials, and the plant itself. One may ask how the San are framing the problem and enrolling allies. Another question is how the plant acts as a boundary object, enabling benefit sharing through its different meanings-as an ethno-pharmaceutical, a part of the San heritage, a biodiverse resource, and a gift from God. Bringing this together with the emphasis in ANT on the nonhuman, one might also address how Hoodia acts as subject. For instance, the plant forces new translational work when its

108. Fujimura, supra note 4, at 170-77. Fujimura notes that Latour and Callon are concermed with fact stabilization and how interests are translated in order to enroll allies. Id. at 171. Star and Griesemer, on the other hand, are interested in the often invisible networks of collaboration across multiple divergent actors. Id. at 170 . Boundary objects thus enable understandings of collaboration, whereas translation through ANT reveals modes of translation through imposition. Id. at 175. As an alternative, Fujimura argues for the concept of "standardized packages" in order to get at both fact stabilization and collective work. Id. at 176 . A standardized package is similar to a boundary object in that it facilitates interactions and serves as an interface between diverse social worlds. Yet, a "package differs from a boundary object in that it defines a conceptual and technical work space which is less abstract, more structured, less ambiguous, and more concrete." Id. at 176. Fujimura deploys standardized packages in order to understand cancer research and its attention towards molecular biology. Id. Translation occurs through standardized packages, consisting of scientific theories and standardized sets of technologies, which enroll members of diverse social worlds around new definitions of cancer. Id. at 177 . Sociolegal scholars, therefore, might also turn to standardized packages as a way of understanding translation within both modes of imposition and collaboration. Annelise Riles, for example, finds collateral to be a standardized package, a constellation of theoretical, material, and aesthetic features that enroll disparate forms of expertise to come together. RILES, supra note 2, at 61-62. The concept of package as less ambiguous and more structured workspace to enroll allies, however, may not be appropriate for all studies. For instance, the concept of boundary object seems more relevant to a study of Hoodia, but the plant may be found to be a standardized package. Socio-legal scholars may find that the conception of boundary objects and standardized packages may both be equally valuable and useful in understanding modes of translation. 
molecular properties do not act how scientists had hoped, disrupting the promise of a global Hoodia-based industry and related benefit-sharing revenues. The notion of boundary objects thus becomes a way to explore the entanglements and ontological politics of the subjects/objects of law's translation. Kregg Hetherington's analysis of the soybean in Paraguay, for example, reveals how the mega-crop acts as a boundary object, entangled within and productive of an assemblage of ecological, political, and economic meanings. ${ }^{109}$ One might also draw from Ballestero and ask how numbers, percentages, and calculations not only act as translational devices, but also as boundary objects. ${ }^{110}$

Despite their divergences, both ANT and boundary objects provide critical insights for socio-legal scholars interested in developing a methodology and praxis of critical cultural translation. In particular, they offer further nuance to Merry's valuable understanding of translation and its dimensions of framing, adapting, and expanding. ${ }^{111}$ How are regulatory orders made? Or as Hetherington argues, how are regulations "additive"?112 Furthermore, how does the making of regulatory orders involve displacement and transformation of legal meanings from one context to the other? How do the human and nonhuman actors involved produce new networks, enroll allies, and mobilize representatives in the making of regulations? How do they work differently through networks of imposition versus collaboration and the fine line between these two? How does the making of regulatory orders produce boundary objects and devices that enable translation? What is the role of nonhuman actors such as documents, files, and standardized forms? How and when does the making of regulatory orders fail? These questions become important inquiries for understanding how legal orders related to the regulation of science are made, circulated, translated, and reconfigured. The goal of such understandings is to provide ways of imagining new regulatory possibilities that enable, rather than disable, coalitions between scientists and nonscientists aimed at producing better science for an inclusive social order.

\section{Feminist Theory and Cultural Translation of Coalition}

Feminist scholarship has produced much insight into how hierarchies of knowledge production are constructed and sustained

109. See generally Kregg Hetherington, Regular Soybeans: Translation and Framing in the Ontological Politics of a Coup, 21 IND. J. GLOBAL. LEGAL STUD. 55 (2014).

110. Ballestero, supra note 65.

111. See MERRY, supra note 2, at 136-37.

112. Hetherington, supra note 109 , at 59. 
through the translation (or not) of ideas from one context to the next. Adrienne Rich reminds women that "our whole life [is] a translation." 113 Knowledge of women's lives and experiences has been given meaning through a masculine language not our own. ${ }^{114}$ Ideas have been translated in ways that obscure the voices of historically marginalized groups. Translation, through the nonsituated universalities of objectivity and Cartesian dualisms, denies and produces the existence and violence of gendered, sexualized, and racialized inequalities. ${ }^{115}$ Dominant modes of translation therefore act as stabilizing translations, keeping hierarchies of power intact, while simultaneously producing them. Marginalized individuals and groups have historically been denied self-expression, remaining only "subjects through translation." 116 Lori Chamberlain notes that metaphors of translation have in fact been historically gendered.117 On one hand, translation metaphors mark the original text as male. ${ }^{118}$ Masculine authority is bestowed upon and secured through an emphasis on origin. On the other hand, such metaphors can also cast the original text as a female object of desire to be overcome and translated into the male translator's (female) mother tongue. ${ }^{119}$

Feminist scholars have turned much of their attention to how the translation of ideas historically constructs and reinforces inequalities. Feminist theory can be read as a counter-narrative, engaging in critical translational work that brings subjugated voices to the forefront to disrupt dominant forms of translation. It is a practice of critical translation itself, demonstrating how the production of knowledge and movement of ideas from one context to another can commit epistemic violence with ontological and material consequences.

Feminist scholars have paid particular attention to the notion of "cultural translation." 20 This notion flows from concerns over how to ensure meaningful understanding and political coalition across difference. ${ }^{121}$ Feminist theory and politics have struggled over how

113. AdRienne Rich, Our Whole Life, in Adrienne Rich's Poetry and Prose 43 (Barbara Charlesworth Gelpi and Albert Gelpi eds., 1993).

114. See Slavova \& Phoenix, supra note 46 , at 335.

115. See Catharine A. MacKinnon, Feminism, Marxism, Method and the State: Toward Feminist Jurisprudence, 8 SIGNS: J. WoMEN CULTURE \& SoC'Y 635, 636 (1983); see also Oyèrónké Oyěwùmi, Visualizing the Body: Western Theories and African Subjects, in AFRICAN GENDER STUDIES: A READER 5 (Oyèrónké Oyěwùmí ed. 2005).

116. See generally Tatman, supra note 46 .

117. Chamberlain, supra note 46 , at 455 .

118. Id

119. Id. at 463 .

120. BUTLER, supra note 46 , at 47 ; Spivak, supra note 46 , at 322 .

121. BUTLER, supra note 46 , at 47-49; Spivak, supra note 46 , at 322-23. 
different historically situated individuals and groups can politically align, even temporarily, toward a common interest without the need for an essentialist and universalizing language of global sisterhood. ${ }^{122}$ Such coalitional politics is rendered difficult because of what Spivak terms a "politics of translation." 123 Spivak contends that feminist work can reinforce dominant modes of translation and also commit translational violence against "Third World women." 124 Specifically, she critiques western feminist translations of Third World feminist texts into English-language texts. ${ }^{125}$ Such translations permit the Third World woman to only speak in English, constructing her in a narrow manner as an accessible figure for claims to an inherent feminist solidarity. ${ }^{126}$ Translated narratives of the Third World woman are thus used to support intrinsic and naturalized assertions of the cross-cultural subordination of all women, which essentializes the category "woman" and flattens gendered experiences of racism and colonialism. A feminist politics grounded in such modes of translation ends up reinforcing and producing the very hierarchies of power and inequality it seeks to dismantle.

Alternatively, Spivak calls for an "intimacy of cultural translation" that begins with a humble understanding of the Third World woman's mother tongue.127 A more meaningful feminist solidarity for Spivak emerges through a "responsible translation" that takes difference into account. ${ }^{128}$ Common alignment can be generated through recognition and understanding of "different differentiations," rather than a universal sisterhood. This is true even if such humble understandings can only ever be partial and continually in flux. ${ }^{129}$ Cultural translation thus becomes an ethical practice toward feminist coalition despite its "impossibility." 130 Cultural translation is, therefore, linked to a feminist politics of temporary coalitional praxis.

122. See generally DANGERous LiAisons: GeNDER, NATION, AND POSTCOLONIAL PERSPECTIVES (Anne McClintock et al. eds., 1997) (discussing the interaction between gender and postcoloniality from an inter-disciplinary perspective); CHANDRA TALPADE MOHANTY, FEMINISM WITHOUT BORDERS: DECOLONIZING THEORY, PRACTICING SOLIDARITY (2003); Oyèrónké Oyěwùmí, The White Woman's Burden: African Women in Western Feminist Discourse, in AFRICAN WOMEN AND FEMINISM: REFLECTING ON THE POLITICS OF SisTERHOOD 86 (Oyèrónké Oyěwùmí ed., 2003); Ella SHOHAT, TALKING VISIONS: MULTICULTURAL FEMINISM IN TRANSNATIONAL AGE (1998).

123. Spivak, supra note 46.

124. Id. at 320.

125. Id. at 314 .

126. Id.

127. Id. at 322 .

128. Id. at 323 .

129. Id.

130. Haraway, supra note 46 , at 585 . 
Judith Butler similarly argues for the possibility of new modes of "cultural translation" that enable a coalitional politics based upon multiple ways of communicating, modes of reasoning, and notions of the subject. ${ }^{131}$ Butler suggests cultural translation as an ethical responsibility whereby:

I cannot muster the "we" except by finding the way in which I am tied to "you," by trying to translate but finding that my own language must break up and yield if I am to know you. You are what I gain through this disorientation and loss. This is how the human comes into being, again and again, as that which we have yet to know. ${ }^{132}$

Through Butler, cultural translation is simultaneously characterized by disorientation, loss, love, and refusal. ${ }^{133}$ Cultural translation may begin with a "playful world-traveling" to know the other, but moves toward an intimacy of knowing (and not knowing) the other self. ${ }^{134}$ Cultural translation involves dimensions of disorientation and loss to develop a more lasting coalitional politics. As ethical responsibility, it becomes a political praxis for a plurality of possible coalitional politics. Feminist notions of cultural translation contribute to and strengthen recent work on "translational research" within science studies. ${ }^{135}$ They also inform socio-legal methodologies of translation that

131. BUTLER, supra note 46 , at 47 .

132. Id. at 49 .

133. Id.

134. María Lugones, Playfulness, "World"-Traveling, and Loving Perception, 2 HYPATLA 3 (1987); BUTLER, supra note 46, at 49; see Thayer, supra note 46.

135. My analysis both contributes to and differs from recent discussions emerging in STS on translational research. See KAUSHIK SUNDER RAJAN, LIVELY CAPITAL: Biotechnologies, Ethics, and Governance IN Global MaRkets (2012). Scientific practitioners deploy the term translational research to refer to the movement of science from bed to bedside and lab to clinic. STS scholars have recently become interested in mapping obstacles within translational research to understand the increasing nexus between science and capital markets. Michael Fisher, for example, examines practices of translational research to address how translation and capital are both lively and changing. See generally Fisher, supra note 5. Translation references movement across scientific fields and technological scales. Id. at 388. Additionally, lively capital is comprised of four facets of capital such as financial, legal, symbolic, and scientific. Id. at 387. Fisher expertly examines how the translation of science from lab to clinic is blocked, for example, by patent ownership rights, internal company rejections, cross-cultural differences among transnational collaborators, regulatory requirements of clinical trials, and physician resistance. Id. at 390 . Although extremely valuable, his use of translation is bound by the practice in which it emanates. Understandings become limited to how translation is understood and experienced within scientific practice itself. This leaves 
draw upon science studies scholarship. What is the point of critical translational work without the goal of social justice? How can socio-legal methodologies of translation engage in responsible cultural translation? How can they enable a coalitional politics for understanding and social change?

\section{CONCLUSION}

As a way of concluding, imagine what a methodology and praxis of critical cultural translation might look like for studying Hoodia patent law struggles. Science studies, for example, provide ways of thinking about how benefit-sharing regulation gets translated when it moves from the legal context of the United Nations to South Africa. How do experts frame the problem of contractual benefit sharing through the language of biodiversity conservation, rather than a discourse of biopiracy, postcolonial politics, or indigenous self-determination? How do experts interest and enroll San peoples as allies in negotiating and signing benefit-sharing contracts that carve out unequal rights and

multiple modes of translation, by those considered non-scientists for example, unaccounted for. Therefore, to address this gap, I suggest that such modes of translation be analyzed through a methodology of translation informed by ANT, boundary objects, and feminist notions of cultural translation. Like Fisher, I am similarly interested in translations from science to market; however, I deploy translation more broadly, extending the network to address variegated hierarchies of power within the nexus of science, law, and capital. For example, how might public, governmental, or Indigenous peoples' responses also impact processes of translational science? More importantly, how might governmental objections shift practices of translational research in different ways, and with more authority, than Indigenous peoples' social movements? I thus agree and highlight Fisher's calls for ethnographic attention to epistemic and material-semiotic objects, sites of deep play, ethical plateaus, and shifts of scale. Id. at 429 . However, my use of critical cultural translation challenges STS and socio-legal scholars to extend their own scales of inquiry to address Indigenous peoples' contributions and responses to practices of translational science that are both productive and symptomatic of contemporary conditions of biocapitalism. In referencing Derrida, Fisher reminds us that because we remain unclear on what it means to be human, we also stay uncertain as to what interests and needs our research should be aimed at. Id. at 427 . Inquiries into translation and lively capital, as ways of understanding such interests and stakes, are thus related to questions of humanness. Critical cultural translation, as ethical responsibility, becomes an important methodological tool within this moment of inquiry. Fisher notes that, according to Derrida, what it means to be human is both to know oneself and to keep open the possibility of self-fashioning through questions of ethics, freedom, and responsibility. Id. at 426. Questions of what it means to be human, however, are different for peoples who have a history of not being characterized as human at all and/or as property, A methodology of critical cultural translation, therefore, contributes to and strengthens emerging science studies work around translation and lively capital by examining the hierarchies within a plurality of possible translations, coalitions, and sciences and as it works towards goals of social justice and a more responsible science. 
privileges that may be counter to the interests of San peoples? What devices are used? How is a plant itself translated and transformed through orders of patent law and benefit sharing? Through a more ecological approach, Star and Griesemer incite us to question the multiple translations at work. How do collaborative negotiations among diverse social worlds of scientists, San peoples, environmental activists, lawyers, and government officials participate in the making of benefitsharing regulations? How does Hoodia emerge as a standardized boundary object with different meanings to secure scientific authority and legal logics of patent law ownership and contractual benefit sharing? Each of these questions provide additional nuance to sociolegal inquiries into how regulatory orders are made through practices of translation involving framing, adapting, and expanding. ${ }^{136}$

The assembly of a socio-legal methodology of translation, however, remains incomplete without an emphasis on responsible cultural translation. What would regulatory orders of patent law and benefit sharing look like if the diverse social actors involved in their making engaged in cultural translational work? How might Hoodia research, and its accompanying regulatory orders, change if scientists willingly experienced the disorientation and loss of yielding to San ways of knowing Hoodia? How can methodologies of critical cultural translation enable the decolonizing of innovation? In other words, how can they make us think differently about how to regulate and promote science? How can scientific regulatory orders be translated through and in support of multiple modes of reasoning, communicating, and knowing the subject, rather than logics of property and ownership? These questions and more become foundational inquiries for a generative discussion of the possibilities for a socio-legal methodology and praxis of critical cultural translation. 
